Available online at

INSECTA

Integrative Science Education and Teaching Activity Journal

Journal homepage : https://jurnal.iainponorogo.ac.id/index.php/insecta

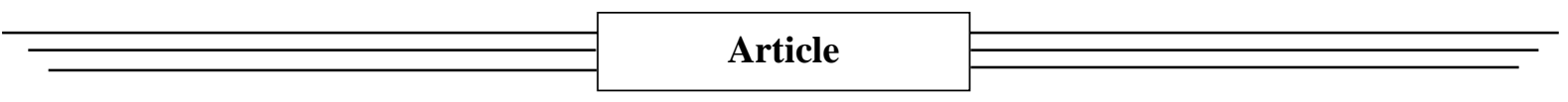

\title{
Validity Analysis of Android-Based Discovery Learning Model to Improve The Understanding of The Physical Concepts
}

\author{
Moh. Apandi G. Jaapar ${ }^{*}$, Abdul Haris Odja ${ }^{2}$, Trisnawaty Junus Buhungo ${ }^{3}$ \\ 1,2,3 Gorontalo State University, Gorontalo, Indonesia \\ * Corresponding Address : fandijaapar@gmail.com
}

\section{Article Info}

Article history:

Received: October 2, 2020

Accepted: October 30, 2020

Published: November 27, 2020

Keywords:

Discovery Lerning,

Understanding Physics

Concepts

\begin{abstract}
This study aims to determine the validity of the discovery learning model assisted by android-based crossword puzzle media in order to see increased understanding of physics concepts. Increased understanding of the concept of physics can be seen from the results of the validity of the instrument whether or not the instrument used is feasible This research method is development research with of Kemp et al (1994) which consists of (1) instructional problems, (2) learner charity, (3) task analysis, (4) instructional, (5) content sequencing, (6) instructional strategic, (7) instructional delevery, (8) evaluation instruments, and (9) instructional response. The results obtained through two validator experts. the validated device was included in the very valid criteria, so it could be concluded that the instrument was very suitable to use
\end{abstract}

(C) 2020 Tadris Ilmu Pengetahuan Alam Department, IAIN Ponorogo, Indonesia.

\section{INTRODUCTION}

The vision of national education is the realization of an empowering and empowering institution so that the Indonesian people develop into qualified people so that they are able and proactive to respond to the challenges of the ever-changing times (Ministry of Education and Culture, Republic of Indonesia: 2015). Over time, IT development as well communication for the purpose of utilizing technological media is directed at efforts to improve the quality of society and education. Baharudin (2010) explains that technology is a large umbrella covering most of the technical equipment for processing and conveying information. The use of relevant software and hardware devices with precondition requirements for the implementation of effective and efficient learning. In line with increasingly advanced In line with increasingly advanced technological advances, to increase the knowledge of students. With adequate technology and information facilitation, it must provide convenience and effectiveness in learning, especially in the use of learning media such as android (smartphone). Teguh Arifianto (2011: 1) explained that android is a linuxbased cellular telephone and operating systems such as tablet computers and smart telephones. 
This device provides an open platform for developers to create their own applications that can be used by a variety of mobile devices. At first, Google Inc. buy Android Inc., a newcomer to developing software namely mobile phones. Then to develop Android, the Open Handset Alliance was formed, a consortium of 34 companies including Nvidia, TMobile, Qualcomm, Motorola, Intel, HTC, Google, as well as software, hardware and telecommunications companies. On the first release of Android, 5 November 2007, Android together with the Open Handset Alliance stated that they fully support the development of open standards on mobile devices. On the other hand, Google releases code \pm Android code under the Apache license, a software license and open standards for mobile devices.

Along with the times, technological developments are also increasingly high and sophisticated, in everyday life the use of smartphone devices is very familiar to the public, more than just their basic functions for calling and texting, some smartphones already have more features and capabilities than their basic functions. This device is in great demand by users because it has an open source nature that motivates developers with Android-based applications. Currently we know more than one application that we can access or download via the Gougle Play Store.

The operating system is designed into the Linux system for hardware such as touch screens on smartphones like those used by the world community in general. explains that Android is an open source software platform for mobile devices. Android contains the operating system, middleware and basic applications. The base of the Android OS is a Linux 2.6 kernel modified for mobile devices.

Teacher dominance causes students' ignorance in understanding physics concepts which are considered very difficult, tend not to be understood, causing students to become more inactive and indifferent so that they wait more for presentations to seek new knowledge. thus, causing students to understand the material being taught does not meet the minimum completeness criteria. which resulted in decreased enthusiasm for learning. To overcome this, educators must choose creative learning strategies to create a conducive atmosphere. The facts found in the field show that understanding the concepts of physics in science lessons is still considered difficult to understand. This fact is still experienced by students who are afraid to learn and lack of enthusiasm results in learning outcomes not meeting the minimum mastery criteria.

The concept of physics is one of the ways to inspire students to seek and discover for themselves so that they gain understanding so that they can help with deeper knowledge. A thoroughly studied concept means authentic and active and is trained to be able to find it on their own. Facts in the field show that physics is still difficult for students to learn. Starting from the experience of the tendency to learn physics is a lesson related to solving complex problems with a mathematical approach to conceptual problems and conceptual understanding (Mertha, 2012:4-5).Learning that motivates students is discovery learning to be replicated in material explanation.

So far, physics learning tends to be teacher-centered and the methods used do not involve students during learning to find a concept. This causes the ignorance of students to obtain the concept of physics for their own discovery, changes in the student's stikma should be made, namely changes from learning that focus on teachers are changed so that they are oriented towards students. (Sofiani, 2011). This requires students to be actively involved as students in learning are less active and have different understanding. Classifying objects or events understanding the concept through the process of obtaining the design of an abstract

INSECTA Volume 1 Number 2, 2020 | p-ISSN 2722-8509 | e-ISSN 2722-8495

Copyright (C) 2020 Moh. Apandi G. Jaapar, Abdul Haris Odja, Trisnawati J. Buhungo 
idea to classify objects and events. Wahyudi (2006) explains that the results of teaching and learning constitute the understanding of each individual and have indicators to define and explain information in one part in his own words. Bloom taxonomy, considering a higher level of understanding. Understanding the concept of many things is the background of the low level of learning using traditional methods and not the contextual Gok (2008) In addition, the ability to understand concepts is less effective so that teachers train students lacking even knowledge of concepts (Brok et al., 2010)

Memorizing, understanding, and memorizing physics concepts and their applications is not easy. Such media is needed to explore knowledge and encourage it. To overcome this problem is a crossword puzzle that has been designed in the form of an application as a learning aid. Hisyam Zaini (2007) explains that Crossword Puzzle is a fun learning without losing the essence of learning and can create pleasant conditions that make students interested and enthusiastic about learning, easy to understand, feel unsaturated and easier to remember the material described. Crossword puzzles are a way to review learning materials after they have been explained. Recalling the lessons given makes it easy to recall what has been conveyed, interesting vocabulary as a learning technique in the form of games can be done casually with various variations. This makes students excited and motivated and stimulates their reasoning power in understanding the material, so that it is easier to remember and becomes a very memorable knowledge that is not easily forgotten as a learning experience that can provide easy and deep understanding.

Crossword puzzle is a game in which the game method is to fill in the empty spaces in the shape of a box with letters to form a word that matches the reference. Besides that, filling out crossword puzzles is really very fun, besides being useful for remembering popular mufradats, but also useful for general knowledge in a relaxed manner. Melihat ciri-ciri tekateki silang yang santai dan mengedepankan persamaan dan perbedaan kosakata, sangat tepat jika misalnya digunakan sebagai alat bantu siswa untuk berlatih di kelas yang diberikan oleh guru, agar dapat menontonnya. dan hanya berupa pertanyaan standar. Dengan kata khasana yang dimiliki oleh seorang pembicara atau penulis, maka kata-kata yang digunakan dalam bidang keilmuan dan daftar kata disusun seperti kamus dan disertai dengan penjelasan yang singkat dan praktis". A person's language skills increase when the quantity and quality of one's vocabulary increases.

To achieve the vision of national education, there is an expectation for students to take part in physics learning, then physics in learning must be in accordance with its essence. Trianto (2009) argues that physics is a scientific activity with the aim of perfecting knowledge about in or to discover new knowledge.

Therefore, it is necessary to hurt the learning development innovation in accordance with the characteristics of physics subjects. The discovery learning model is seen in accordance with the essence of physics lessons. This suitability is because learning focuses on mental intellectuals to solve the various problems faced. Slavin (2005) explains discovery learning has the opportunity to be actively involved in learning, through active engagement with concepts with the principle of breaking through experiences by carrying out activities enabling them to get their own concepts and principles. Putrayasa (2014) also explained that through learning discoveries assisted by crossword puzzel media made students closer to their learning references, students' confidence would be more motivated because what they understood was found by themselves and added to the experience of students. The reason for

INSECTA Volume 1 Number 2, 2020 | p-ISSN 2722-8509 | e-ISSN 2722-8495 Copyright (C) 2020 Moh. Apandi G. Jaapar, Abdul Haris Odja, Trisnawati J. Buhungo 
choosing the discovery learning learning model is that this learning model focuses or is more dominant in learning carried out by students who make students think creatively to find the concepts being learned.

In discovery learning learning aids in learning are used, namely crossword puzzles that are designed into the form of android, the reason for using crossword puzzles as a learning tool is that crossword puzzles can help review, remember so that students understand the material being taught. Weisskirch (2006) explains that the crossword puzzle is a way to review learning materials after they are explained. Recalling the lessons given makes it easy to remember what was said. Silberman (2010) also argues that he thinks that TTS is an interesting vocabulary as a learning technique in the form of a game that can be done casually with various variations. This makes students excited and motivated and stimulates their reasoning power. To understand the material, so that it is easier to remember and becomes a very memorable knowledge that is not easily forgotten as a learning experience that can provide easy and deep understanding.

Based on the description above, the formulation of the problem in this study is "how is the feasibility of physics learning tools using discovery learning models assisted by crossword puzzle media based on android to improve understanding of physics concepts"

\section{METHODS}

This is being researched is development of Kemp et al (1994) which consists of (1) instructional problems, (2) learner charity, (3) task analysis, (4) instructional, (5) content sequencing, (6) instructional strategic, (7) instructional delivery, (8) evaluation instruments, and (9) instructional response. The choice of this model is because each development is directly related to revision activists. The validated tools include: lesson plans, teaching materials, student worksheets (LKPD), and cognitive tests to improve understanding of physics concepts. The process of validation validation was carried out by two experts so as to produce data that was analyzed qualitatively descriptively. To provide an interpretation of the validity of the instrument, Riduwan (2013: 94) describes the validity criteria as follows

Table 1. Validity criteria

\begin{tabular}{cc}
\hline Score Criteria & Category \\
\hline $3,6 \leq 4$ & Very Valid \\
$2,6 \leq 3,5$ & Valid \\
$1,6 \leq 2,5$ & Enough \\
$1 \leq 1,5$ & Less Valid \\
\hline & (Riduwan, 2013:94)
\end{tabular}

\section{RESULTS AND DISCUSSION}

Study include: lesson plans, teaching materials, student worksheets (LKPD), and cognitive tests to improve understanding of physics concepts. The development process in this model refers to Kemp et al (1994). Next will be briefly explained the results of the validity of the learning device using the discovery learning model assisted by the crossword puzzle media android based.

1. Lesson Plan

The Learning Implementation Plan (RPP) developed by the researcher refers to the characteristic analysis of students, so the lesson plan is carried out in three meetings with a time allocation of $2 \times 40$ minutes per meeting. The results obtained through two validator experts are as follows

INSECTA Volume 1 Number 2, 2020 | p-ISSN 2722-8509 | e-ISSN 2722-8495 Copyright (C) 2020 Moh. Apandi G. Jaapar, Abdul Haris Odja, Trisnawati J. Buhungo 
Table 2. RPP validation results

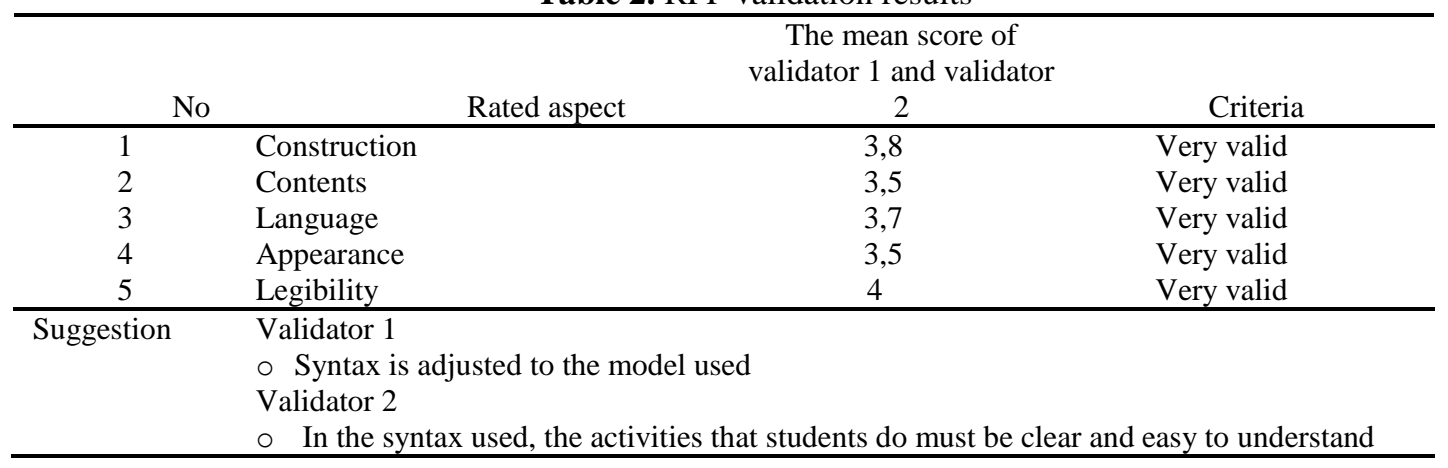

1. Teaching materials

Two experts also validated the teaching materials to see their feasibility, so that the data obtained were as follows.

Table 3. Results of the validity of teaching materials

\begin{tabular}{clcl}
\hline & & $\begin{array}{c}\text { The mean score of validator 1 } \\
\text { and validator 2 }\end{array}$ & Criteria \\
\hline No & Rated aspect & 3,7 & Very valid \\
2 & Construction & 3,5 & Very valid \\
3 & Contents & 3,8 & Very valid \\
4 & Language & 3,7 & Very valid \\
5 & Appearance & 4 & Very valid \\
\hline Suggestion & Legibility & Validator 1 & \\
& $\circ \quad$ The material is brief and clear & \\
& $\circ \quad$ Images that are presented are adjusted to the meteri \\
& Validator 2 & \\
& $\circ \quad$ Add source of the included image &
\end{tabular}

\section{Student Worksheet (LKPD)}

The learning tool developed by the researcher was a student worksheet (LKPD) which was validated by two validator experts with the following results.

Table 4. Results of validation of student worksheets (LKPD)

\begin{tabular}{clcc}
\hline & \multicolumn{3}{c}{$\begin{array}{c}\text { The mean score of validator 1 } \\
\text { and validator } 2\end{array}$} \\
No & Rated aspect & 3,8 & Criteria \\
\hline 1 & Construction & 3,5 & Very valid \\
2 & Contents & 3,3 & Very valid \\
3 & Language & 3,8 & Valid \\
4 & Legibility & Very valid \\
\hline Suggestion & Validator 1 & \\
& O In work procedures, clear language and meaning \\
& Validator 2 & \\
& O There needs to be a picture related to what students do, so that \\
& young students understand & \\
\hline
\end{tabular}

\section{DISCUSSION}

In the learning implementation plan (RPP) Based on Table 2 above, it can be seen that on average the RPP that has been developed is valid and feasible for use. This is because it is in accordance with Permendiknas Number 41 of 2007 concerning standard processes, especially on components. Majid (2008) explains that RPP includes subject identity, competency standards, basic competencies, competency achievement indicators, learning objectives, teaching materials, time allocation, learning methods, learning activities, assessment of learning outcomes, learning resources.

In addition, the RPP prepared is valid because the aspects of format, language, and content are in accordance with or meet the criteria for a good lesson plan. However, the 
construction and language aspects get the smallest average compared to the other two aspects. This is because it still needs improvement, the syntax is adjusted to the model used and the activities carried out by students must be clear. Therefore, the researcher made a revision in accordance with the suggestions of the validator so that it is hoped that after the revision the device can be more helpful in the learning process.

The teaching materials were carried out based on the results of the researcher's analysis of: (1) analysis of the characteristics of students (aiming to determine the level of cognitive development, background knowledge, and socio-cultural background of students; (2) problems in learning and analysis. According to Table 3 It is known that on average the five aspects have a very valid criterion average, with some suggestions from the validator among the material presented must be concise and clear, the pictures included are adjusted to the material and the source, meaning that the learning materials developed by students are very suitable for use. in the learning process.

Students in the development process are based on several analyzes which include: (1) objective analysis (referring to several theories about discovery learning models. As a consideration in preparing the LKPD discovery learning stages so that the LKPD) reflects the character of the discovery that begins with the stages of formulating problems through questions, making hypotheses, designing and conducting experiments, collecting and analyzing data, and making conclusions. What the experts have checked with some suggestions. By improving language work procedures and their meaning must be clarified, it is necessary to have pictures related to what students do, so that young students understand.

Crossword puzzles are made through Game Maker masters. Crossword puzzles are made with a design that contains questions and learning materials to be given to students, then supplied together in the form of an application, so that younger students can access and install on the students' androids. Crossword puzzle media is used as a tool in the learning process. Before entering the learning process, students must first install the application on their respective Android. Once installed, students will be given a simulation of how to use the crossword puzzle in the learning process. The crossword puzzle media becomes the guide for students in the learning process because it already contains the materials to be taught. In addition, students can fill in the questions on the crossword puzzle designed to make them younger in understanding and remembering the lessons that have been conveyed.

In the use of crossword puzzles that are designed in the form of an application as a learning tool, they are used as a guide in the learning process because they already contain the material being learned, besides containing learning materials, it is also equipped with vocabulary games that are arranged vertically and horizontally in the form of a box containing questions - questions related to the material being taught that make students enthusiastic and enthusiastic in following the lessons because they contain elements of play that are fun and not boring.

\section{CONCLUSION}

Based on the validity of the discovery learning model assisted by android-based crossword puzzle media to improve understanding of physics concepts and discussion, it can be concluded that the development of learning tools is feasible for use in physics learning.

\section{REFERENCES}

Baharudin, R. (2010). Keefektifan Media Belajar Berbasis Teknologi Informasi Dan Komunikasi. Jurnal pendidikan, Tadrîs, 5(1), 112-127

Brok, P. D. R. \& Fisher, D. (2010). How well do Science Teacher Do? Differences in teacherstudent interpersonal behavior between Science Teachers and teachers of other (school) Subjects. The open education Journal,3 
Gok, T. \& Silay, I. (2008). Effect of Problem Solving Strategy Teaching on the problem solving attitude of cooperative learning group. Journal of Theory and practice in education.4(2)

Hisyam, Z. (2007). Psikologi Pendidikan dengan pendekatan baru. Bandung : PT Remaja Rosdakarya

Kementrian Pendidikan dan Kebudayaan, Republik Indonesia : 2015

Kemp, J.E. Gary, R.M. \& Steven, M.R. (1994). Designing Effective Instruction. New York : Macmillan College Publishing Company.

Majid, A. (2008). Perencanaan Pembelajaran : Mengembangkan Standar Kompetensi Guru. Bandung. PT Remaja Rosdakarya.

Mertha, Y. \& I Made, A.(2012) Pengaruh Model Pembelajaran Cooperative Guided Inquiry Labs Dan Individual Guided Inquiry Labs Terhadap Pemahaman Konsep Fisika Siswa ditinjau dari Gaya Kognitif. Jurnal IPA Undiksha, 4-5.

Putrayasa, I.H. \& Margunayasa, I. (2014). Pengaruh Model Pembelajaran Discovery Learning Dan Minat Belajar Terhadap Hasil Belajar Ipa Siswa, II(1), 1-11.

Riduwan. (2013). Metode dan Teknik Penyusunan Tesis. Bandung: Alfabeta

Silberman, M. (2010). Active Learning. Yogyakarta: Pustaka Belajar.

Slavin, R. (2005).Cooperative Learning Teory, Riset dan Praktik diterjemahkan oleh Narilita Yusron. Bandung : Nusa Media.

Sofiani. (2011). Sinopsis Obstetri jilid 2.Jakarta : EGC.

Trianto. (2009). Model Pembelajaran Terpadu. Jakarta: PT Bumi Aksara

Weisskirch. (2006). Reviewing for Exams: Do CrossWord Puzzles Help in the Success of Student Learning?. The Journal of Effective Teaching, 9(3), 4-10. 